\title{
The GPER1 Agonist G-1 Attenuates Endothelial Cell Proliferation by Inhibiting DNA Synthesis and Accumulating Cells in the $S$ and $G 2$ Phases of the Cell Cycle
}

\author{
Anders Holm $^{a}$ Bo Baldetorp ${ }^{b}$ Björn Olde ${ }^{a} \quad$ L.M. Fredrik Leeb-Lundberg ${ }^{a}$ \\ Bengt-Olof Nilsson ${ }^{a}$ \\ Departments of a Experimental Medical Science and ${ }^{b}$ Clinical Sciences, Lund University, Lund University Hospital, \\ Lund, Sweden
}

\section{Key Words}

Cell cycle $\cdot$ DNA synthesis $\cdot$ Endothelial cells $\cdot$ Estrogen

Estrogen receptor $\cdot$ G-1 $\cdot$ GPER1

\begin{abstract}
G protein-coupled receptor 30 (GPR30) or G protein-coupled estrogen receptor 1 (GPER1) is expressed in the vasculature, but the importance of vascular GPER1 remains to be clarified. Here we investigate effects of the GPER1 agonist G-1 on endothelial cell proliferation using mouse microvascular endothelial bEnd. 3 cells. The bEnd. 3 cells express MRNA for GPER1. The bEnd. 3 cells expressed both ER $\alpha$ and ER $\beta$ immunoreactivities. Treatment with G-1 reduced DNA synthesis and cell number with $\mathrm{IC}_{50}$ values of about $2 \mu \mathrm{M}$. GPER1 siRNA prevented G-1-induced attenuation of DNA synthesis. G-1 accumulated cells in $S$ and $G 2$ phases of the cell cycle, suggesting that G-1 blocks transition between G2 and M. G-1 had no effect on DNA synthesis in COS-7 cells only weakly expressing GPER1 mRNA. 17ß-Estradiol had no effect on DNA synthesis in physiological concentrations (nM). The ER blocker ICI182780 reduced DNA synthesis with similar potency as G-1. Treatment with the ERK/MAP kinase inhibitor PD98059 had no effect on G-1-induced attenuation of DNA synthesis. G-1induced antiproliferation was observed not only in bEnd.3
\end{abstract}

cells but also in human umbilical vein endothelial cells and HMEC-1 endothelial cells. We conclude that the GPER1 agonist G-1 attenuates endothelial cell proliferation via inhibition of DNA synthesis and by accumulation of cells in $S$ and $G 2$.

Copyright $\odot 2011$ S. Karger AG, Basel

\section{Introduction}

The female sex hormone estrogen possesses atheroprotective effects, observed in premenopausal women being less prone to cardiovascular disease than age-matched men $[1,2]$. Several mechanisms have been suggested for the cardiovascular protective effect of estrogen, for example attenuation of vascular inflammation [3, 4], stimulation of $\mathrm{NO}$ formation [5] and prevention of vascular smooth muscle cell proliferation [6]. An intact endothelium is important for prevention of cardiovascular disease, and it is possible that the atheroprotective effects of estrogen are mediated through improved endothelial healing $[7,8]$.

Estrogen exerts its effect via two classical estrogen receptor subtypes named ER $\alpha$ and ER $\beta$ [9]. Expression of $\mathrm{ER} \alpha$ and ER $\beta$ has been shown in endothelial and vascular smooth muscle cells on both mRNA and protein levels

\section{KARGER}

Fax +41613061234 E-Mail karger@karger.ch www.karger.com

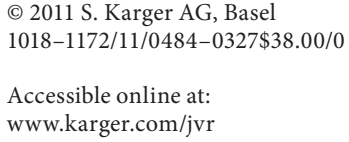

\footnotetext{
Dr. Bengt-Olof Nilsson

Department of Experimental Medical Science

Lund University, BMC D12

SE-221 84 Lund (Sweden)

Tel. +46 46222 7767, Fax +46 46222 4546, E-Mail bengt-olof.nilsson@med.lu.se
} 
$[10,11]$. Estrogen has been shown to prevent vascular smooth muscle cell proliferation after vascular injury via $\mathrm{ER} \alpha$ [6]. Studies in knockout mice have shown that ER $\alpha$ is critical for estrogen-induced improvement of re-endothelialization, while ER $\beta$ is not [7]. Also estrogen-induced anti-inflammatory effects have been reported to be mediated via $\mathrm{ER} \alpha$ [12]. Estrogen has been reported to induce eNOS and increase NO production within minutes and this effect was attributed to a subpopulation of ER $\alpha$ (ER $\alpha 46)$ residing in the plasma membrane $[13,14]$. Thus, a lot of evidence suggests that ER $\alpha$ mediates estrogeninduced vasculoprotection.

G protein-coupled receptor 30 (GPR30), now named G protein-coupled estrogen receptor 1 (GPER1), has been reported to bind $17 \beta$-estradiol with high affinity $[15,16]$. GPER1 was shown to mediate proliferative effects of $17 \beta$ estradiol in breast cancer cells lacking ER $\alpha$ and ER $\beta$ [17]. Studies in GPER1 knockout mice have revealed that these mice show reduced amount of $\mathrm{T}$ lymphocytes expressing CD62L, hyperglycaemia, reduced body growth, reduced serum IGF-I levels and increased blood pressure [18-20]. Mesenteric arteries and endothelial cells have been shown to express GPER1, suggesting a functional role for GPER1 in the vascular system $[18,19]$.

Haas et al. [21] reported recently that the GPER1 agonist G-1, identified and characterized by Bologa et al. [22], reduces vascular smooth muscle cell proliferation when administered in micromolar concentrations, suggesting that G-1 might be used as a blocker of unwanted vascular smooth muscle cell proliferation in atherosclerosis. In order to obtain a more complete picture of how G-1 affects vascular function, not only the effects of G-1 on vascular smooth muscle cells, but also its effects on endothelial cells, have to be considered. Therefore, we investigated the effects of G-1 on endothelial cell proliferation and disclose that G-1, in the micromolar concentration range, exerts an antiproliferative effect on microvascular endothelial cells by inhibiting DNA synthesis and accumulating cells in the S and G2 phases of the cell cycle.

\section{Material and Methods}

\section{Cell Culture}

The mouse brain microvascular endothelial cell line (bEnd.3) was purchased from American Type Tissue Culture Collection (Manassas, Va., USA) and cultured in Dulbecco's modified Eagle's medium, supplemented with $10 \%$ fetal calf serum (FCS) and antibiotics (penicillin $100 \mathrm{U} / \mathrm{ml}$, streptomycin $100 \mu \mathrm{g} / \mathrm{ml}$ ). The human dermal microvascular endothelial cell line HMEC-1 was cultured in Gibco MCDB 131 medium supplemented with 10\%
FCS, $10 \mathrm{ng} / \mathrm{ml}$ epidermal growth factor and antibiotics. COS-7 cells were cultured in Dulbecco's modified Eagle's medium, supplemented with $10 \%$ FCS and antibiotics (penicillin $100 \mathrm{U} / \mathrm{ml}$, streptomycin $100 \mu \mathrm{g} / \mathrm{ml}$ ). Human umbilical vein endothelial cells (HUVEC) were purchased from Lonza (Walkersville, Md., USA) and cultured in endothelial cell culture medium as recommended by the manufacturer. Cell culture dishes were placed in a waterjacketed cell incubator at $37^{\circ} \mathrm{C}$ in $5 \% \mathrm{CO}_{2}$ in air. Experiments were performed when cells reached $80 \%$ confluence. Before experiments, normal culture medium was replaced with phenol red-free and FCS-free culture medium for $24 \mathrm{~h}$, or $3 \mathrm{~h}$ for HUVEC, to make cells quiescent and to remove the estrogen-like activity of phenol red. The phenol red-free culture medium was used throughout the experiment. Experiments were normally performed under growth-arrested conditions ( $0 \%$ FCS), but in some experiments cells were growth stimulated with (5\%) dextrancoated charcoal-stripped FCS. Dextran-coated charcoal was used to remove steroids from normal FCS.

\section{Cell Counting and Cell Viability}

Number of cells was determined by cell counting in a Bürker chamber after trypsination (0.25\%). Cell viability was assessed by trypan blue exclusion test. After removing culture medium cells were washed with $0.9 \% \mathrm{NaCl}$ and incubated for 2 min with $0.4 \%$ trypan blue (Sigma Chemicals, St. Louis, Mo., USA). Then the cells were washed three times and the number of cells containing trypan blue was determined as a measure of dead/dying cells.

\section{RT-PCR}

The bEnd.3, COS-7 and RAW264.7 cells were washed carefully in PBS and then total RNA was extracted and purified using RNeasy Mini Kit (Qiagen, Valencia, Calif., USA). cDNA was generated and mRNA for GPER1 determined as previously described by Mårtensson et al. [19]. Reverse transcriptase-negative controls were included to exclude the presence of contaminating genomic DNA. The sequences of GPER1 (GPR30) primers employed are as follows: forward, GATCGTTAGATTAACAGAGCAG; reverse, CCTGGGAGCCTGTTAGTCTCAG. This primer pair produces a GPR30-specific product [19]. One-step quantitative real-time PCR measurements were performed using QuantiFast SYBR Green RT-PCR kit (Qiagen) and QuantiTect primer assays (Qiagen) on a Step One Plus real-time thermal cycler from Applied Biosystems (Foster City, Calif., USA). Each sample was analyzed in duplicate. GPER1 gene expression was calculated using GAPDH as reference gene as described by Pfaffl [23]. The PCR primers (QuantiTect Primer Assays) for GPER1 (Mm_Gper_1_ SG) and GAPDH (Mm_Gapdh_3_SG) were from Qiagen.

\section{Immunocytochemistry}

Cells grown on glass cover slips were fixed in $4 \%$ formaldehyde in PBS for $2 \mathrm{~h}$ at $4^{\circ} \mathrm{C}$. After washing in PBS, the cells were incubated with polyclonal ER $\alpha$ (NeoMarkers, Fremont, Calif., USA; code Ab-16) or ER $\beta$ (Affinity BioReagents, Golden, Colo., USA; code PA1-311) antibodies raised in rabbits at dilution of 1:100. $\mathrm{ER} \alpha$ and ER $\beta$ antibodies were purchased from Thermo Scientific (Waltham, Mass., USA). For visualization of ER $\alpha$ and ER $\beta$ immunoreactivity a fluorescein isothiocyanate-conjugated swine anti-rabbit antibody (Jackson Immuno Research Laboratories, West Grove, Pa., USA) was used. For negative controls, the primary antibody was omitted. 
DNA Synthesis Measurement

DNA synthesis was determined by measuring incorporation of $\left[{ }^{3} \mathrm{H}\right]$ thymidine. The isotope was included for the last hour of the 24-hour incubation. The cells were washed in PBS and then harvested using a rubber policeman. Cells were sonicated in $5 \mathrm{M}$ $\mathrm{NaOH}$ twice for $10 \mathrm{~s}$. Aliquots of the sonicate were precipitated with $5 \%$ trichloroacetic acid and centrifuged $(10,621 \mathrm{~g}$ for $2 \mathrm{~min}$ at $4^{\circ} \mathrm{C}$ ). After washing with trichloroacetic acid the pellet was dissolved in soluene. Liquid scintilliation cocktail was added and radioactivity measured in a liquid scintilliation counter (Beckman, Fullerton, Calif., USA). Protein concentration was determined by using a Bio-Rad protein assay kit (Bio-Rad, Hercules, Calif., USA) based on the Lowry method [24]. Radioactivity was expressed as DPM and normalized to the concentration of total protein in each sample.

\section{GPER1 siRNA}

The bEnd. 3 cells were treated with commercially available GPER1 siRNA (accession No. S104924283) or scramble control (scramble, accession No. S103650325) purchased from Qiagen. Free-floating, newly trypsinated cells were treated with the GPER1 siRNA or scramble control and HiPerFect transfection reagent (Qiagen) for $3 \mathrm{~h}$ in serum-free and antibiotic-free culture medium. The final siRNA and scramble control concentration was $100 \mathrm{nM}$ as recommended by the manual from Qiagen. The cells were allowed to attach and equilibrate for $48 \mathrm{~h}$ in normal culture medium before being challenged with G-1 or DMSO vehicle. A lower GPER1 mRNA level in siRNA- versus scramble control-treated bEnd. 3 cells, demonstrated by quantitative realtime PCR, confirmed downregulation of GPER1 transcript by GPER1 siRNA.

\section{Flow Cytometry}

Distribution of bEnd. 3 cells in the cell cycle was determined by flow cytometry of propidium iodide-stained nuclei as described by Odenlund et al. [25]. Briefly, flow-cytometric DNA analysis was performed in a FACSCalibur flow cytometer (Becton Dickinson Immunocytometry Systems, San José, Calif., USA) equipped with Cell Quest PRO ${ }^{\mathrm{TM}}$ program for data acquisition. DNA contents were determined in about 13,000 nuclei in each sample. Processor signals were digitized and sorted into frequency distribution, DNA histograms, with 256 units resolution. Cell cycle phase distribution was determined by using ModFit LT 3.1 (Verity Software House Inc., Topsham, Me., USA).

\section{Drugs}

G-1 was purchased from Cayman Chemical (Ann Arbor, Mich., USA). $E_{2}$ was purchased from Sigma Chemicals. ICI182780 was a kind gift from Zeneca Pharmaceuticals (Macclesfield, UK). PD98059 was purchased from Calbiochem (San Diego, Calif., USA). G-1, E $E_{2}$, ICI182780 and PD98059 were dissolved in DMSO. Controls received DMSO as vehicle.

\section{Statistics}

Summarized data are presented as means \pm SEM. Statistical significance was calculated using ANOVA and Student's twotailed $t$ test for unpaired comparison with Bonferroni correction for post hoc analysis as appropriate.

G-1 Reduces Endothelial Cell

Proliferation

\section{Results}

Expression of GPER1, ER $\alpha$ and ER $\beta$ in bEnd.3

\section{Endothelial Cells}

In order to characterize ER expression in the bEnd. 3 cells, we determined GPER 1 mRNA and ER $\alpha$ and ER $\beta$ protein expression. The bEnd. 3 cells expressed mRNA for GPER1 as demonstrated in figure 1a. For positive control we used mouse macrophage RAW264.7 cell cDNA (fig. 1a). The RAW264.7 cells are well known to express GPER1 [26]. In COS-7 cells a weak GPER1 band was detected showing that these cells only weakly express GPER1 mRNA (fig. 1a). This is in agreement with previous studies reporting that COS-7 cells lack GPER1 expression or only show weak GPER mRNA expression [27, 28]. Since there is no reliable antibody available for mouse GPER1, we could not confirm GPER1 transcript expression on the protein level. The bEnd. 3 cells expressed ER $\alpha$ and ER $\beta$ proteins as demonstrated by immunocytochemistry (fig. 1b). ER $\alpha$ and ER $\beta$ immunoreactivities were mainly observed in the nuclei, but some ER $\beta$ immunoreactivity was also observed in the cytoplasm.

\section{Effects of G-1 on bEnd.3 Cell DNA Synthesis}

Stimulation with a submaximal concentration of charcoal-stripped FCS (5\%) for $24 \mathrm{~h}$ increased DNA synthesis by about 3 -fold compared to the basal level of DNA synthesis ( $0 \%$ FCS) as shown in figure 2 . Treatment with G-1 at a low concentration $(0.03 \mu \mathrm{M})$ had no effect on FCS-stimulated DNA synthesis, while a higher concentration $(3 \mu \mathrm{M})$ fully prevented FCS-induced DNA synthesis (fig. 2). An intermediate concentration of G-1 (0.9 $\mu \mathrm{M})$ also reduced FCS-induced DNA synthesis, but this effect was not statistically significant (fig. 2). G-1 caused a concentration-dependent decrease in DNA synthesis under nonstimulated ( $0 \%$ FCS) basal conditions with an $\mathrm{IC}_{50}$ value of about $1.9 \mu \mathrm{M}$ (fig. 3). As seen in figure 4, stimulation with G-1 ( $3 \mu \mathrm{M})$ for $24 \mathrm{~h}$ reduced basal DNA synthesis by about $80 \%$. An equimolar concentration $(3 \mu \mathrm{M})$ of the endogenous estrogen $17 \beta$-estradiol also reduced DNA synthesis (30\%), but the effect of $17 \beta$-estradiol was smaller than that of G-1. Because $3 \mu \mathrm{M}$ is not a physiological concentration of $17 \beta$-estradiol, we also tested lower concentrations (0.1-30 nM) of this estrogen. As shown in figure 4, treatment with $0.1-30 \mathrm{nM} 17 \beta$-estradiol had no effect on DNA synthesis. Combined treatment with $3 \mu \mathrm{M} 17 \beta$-estradiol as well as the ER $\alpha$ and ER $\beta$ antagonist ICI182780 $(1 \mu \mathrm{M})$ reduced DNA synthesis by about $80 \%$ (fig. 4). Treatment with $1 \mu \mathrm{M}$ ICI 182780 alone reduced DNA synthesis similar to the combination 


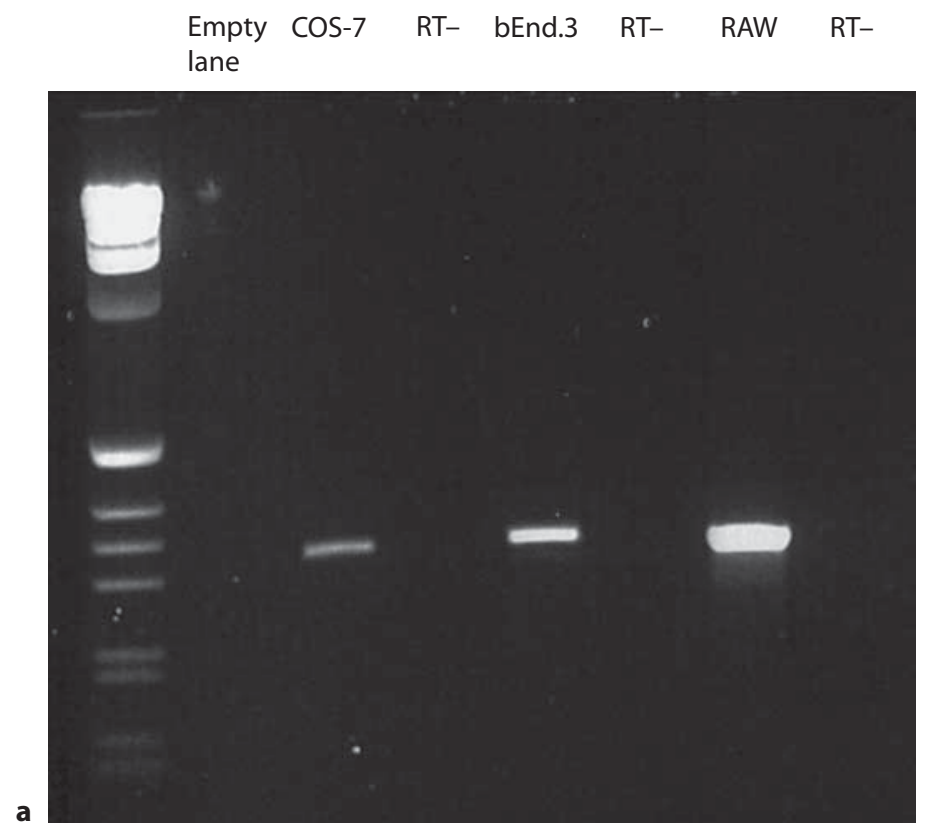

Fig. 1. a The bEnd. 3 cells express a strong GPER1 mRNA band (GPR30, $290 \mathrm{bp}$ ) as demonstrated by RT-PCR. The leftmost panel shows the DNA ladder. No band was observed in reverse transcriptase-negative (RT-) control. RAW264.7 cell cDNA (RAW) was used as positive control producing a very strong 290-bp
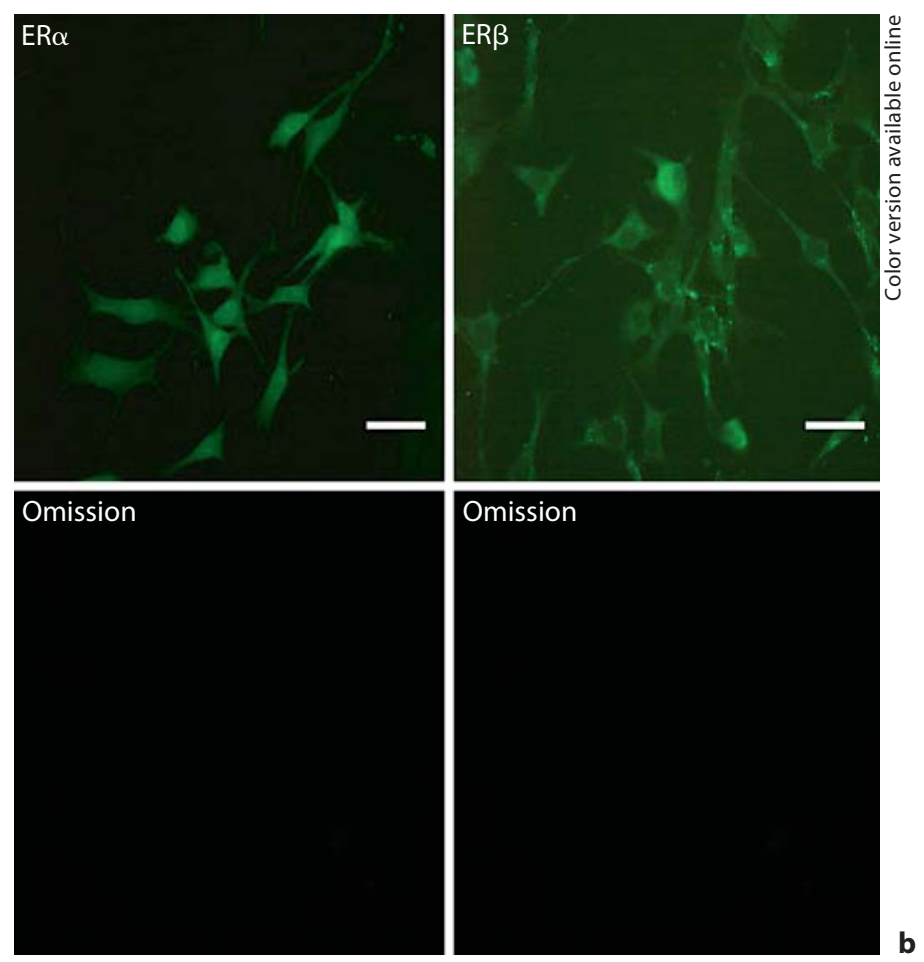

GPER1 band. In COS-7 cells a very weak 290-bp GPER1 band was observed. $\mathbf{b}$ The bEnd. 3 cells express immunoreactivity for ER $\alpha$ as well as ER $\beta$ as demonstrated by immunocytochemistry. No immunoreactivity was observed after omission of the primary $\mathrm{ER} \alpha$ or $\mathrm{ER} \beta$ antibodies. Scale bars $=20 \mu \mathrm{m}$. of $17 \beta$-estradiol and ICI182780 (fig. 4). To provide direct evidence for the involvement of GPER 1 we treated bEnd. 3 cells with GPER1 siRNA and scramble control, respectively, and then monitored the effects of 24-hour treatment with G-1 on FCS (5\%)-stimulated DNA synthesis. G-1 $(3 \mu \mathrm{M})$ reduced DNA synthesis by $60 \%$ in scramble control, while it had no effect in GPER1 siRNA-treated cells (fig. 5a). Downregulation of GPER1 mRNA level by siRNA was confirmed by quantitative real-time PCR (fig. 5b).

We tested the effects of G-1 on DNA synthesis in a human microvascular endothelial cell line as well, that is, human dermal microvascular endothelial HMEC-1 cells [29]. Treatment with G-1 ( $3 \mu \mathrm{M})$ for $24 \mathrm{~h}$ under nonstimulated $(0 \%$ FCS) basal conditions reduced DNA synthesis by about $50 \%$ in HMEC-1 cells (fig. 6), showing that G-1 reduces DNA synthesis in microvascular endothelial cells derived from a different origin than bEnd. 3 cells as well. Treatment with $3 \mu \mathrm{M} \mathrm{G}-1$ for $24 \mathrm{~h}(0 \% \mathrm{FCS})$ reduced DNA synthesis by about $80 \%$ in HUVEC (fig. 6). We com- pared the effects of G-1 on DNA synthesis in GPER1positive bEnd. 3 cells with those in COS-7 cells only weakly expressing GPER1 $[27,28]$. As demonstrated in figure 6, treatment with G-1 ( $3 \mu \mathrm{M})$ for $24 \mathrm{~h}(0 \%$ FCS) reduced DNA synthesis by about $80 \%$ in bEnd. 3 cells, but had no effect in COS-7 cells.

\section{Effects of G-1 on bEnd.3 Cell Number and Cell Cycle \\ Phase Distribution}

Treatment with G-1 (3 $\mu \mathrm{M})$ for 5 days reduced the cell number by about $75 \%$ under conditions representing submaximal growth stimulation, that is, $5 \%$ charcoalstripped FCS (fig. 7a). Treatment with $3 \mu \mathrm{M}$ G-1 for a shorter time, that is, 2 days, reduced cell number by about $65 \%(70,000 \pm 4,100$ cells $/ \mathrm{ml}$ after G-1 treatment vs. $215,000 \pm 45,000$ cells $/ \mathrm{ml}$ in controls, $\mathrm{p}<0.05, \mathrm{n}=4$ in each group). Trypan blue exclusion test of cells cultured with 5\% stripped FCS showed very few trypan blue-containing cells in both control cells and cells treated with $3 \mu \mathrm{M}$ G-1, suggesting that G-1 has no effect on cell viabil- 


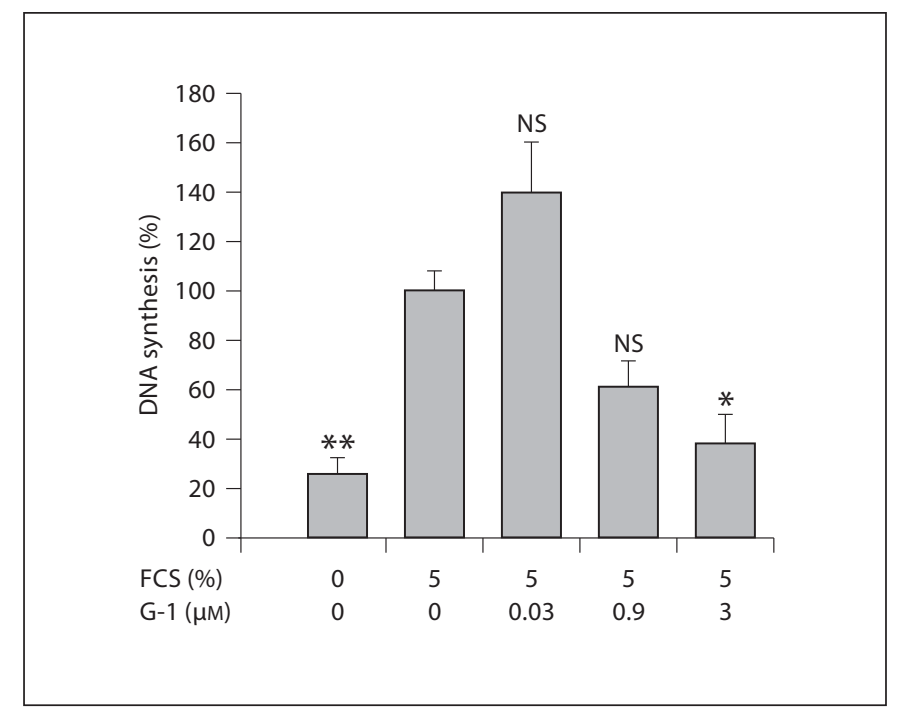

Fig. 2. G-1 ( $3 \mu \mathrm{M})$ prevents FCS-induced DNA synthesis in bEnd.3 cells growth-stimulated with 5\% stripped FCS for $24 \mathrm{~h}$. Cells were pretreated with G-1 for 2 h before FCS was introduced. G-1 was then present throughout the 24 -hour incubation. DNA synthesis was determined by incubation with radiolabeled thymidine during the last hour of incubation $\left(\left[{ }^{3} \mathrm{H}\right]\right.$-thymidine, $\left.5 \mu \mathrm{Ci}\right)$. Radioactivity was normalized to protein concentration and presented as per cent of the radioactivity in parallel controls. Values are means \pm SEM of 3-11 observations in each group. ${ }^{*} \mathrm{p}<0.05 ;{ }^{* *} \mathrm{p}<0.01$ compared to cells stimulated with $5 \%$ FCS alone. NS = Not significant compared to $5 \%$ FCS.

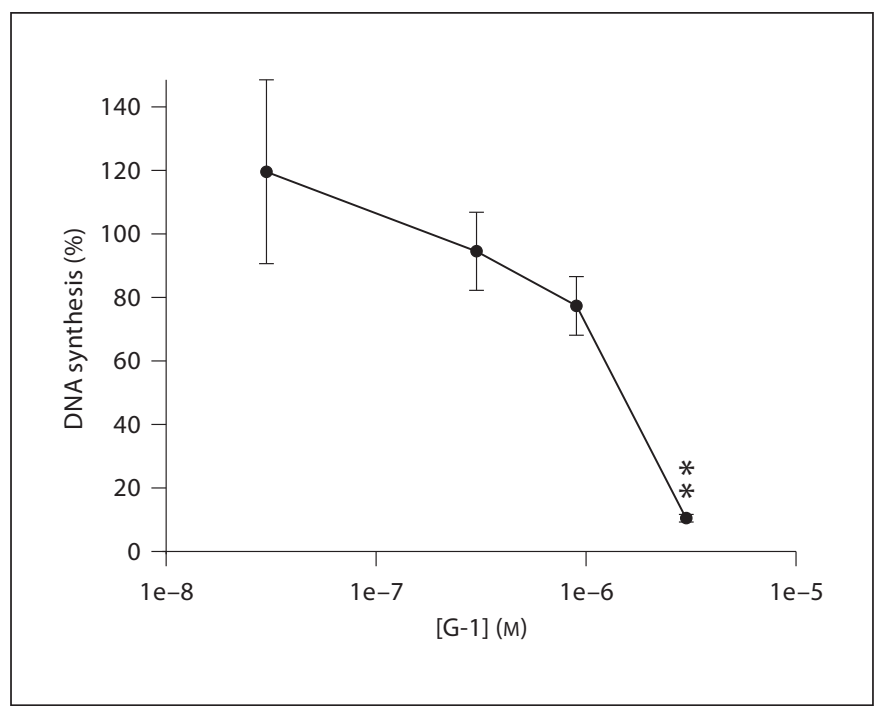

Fig. 3. Dose-response curve showing the effects of increasing concentrations of G-1 on DNA synthesis in bEnd. 3 cells. DNA synthesis in cells treated with G-1 was normalized to that observed in untreated control cells. DNA synthesis in control cells was set to $100 \%$. The cells were treated with G-1 for $24 \mathrm{~h}$ under nonstimulated ( $0 \%$ FCS) basal conditions. The $\mathrm{IC}_{50}$ value was calculated to $1.9 \mu \mathrm{M}$. Values are means \pm SEM of 5-9 observations in each group. ${ }^{* *} \mathrm{p}<0.01$ compared to controls.
Fig. 4. Effects of treatment with $17 \beta$-estradiol, ICI182780 and G-1 for $24 \mathrm{~h}$ on DNA synthesis in bEnd. 3 cells ( $0 \%$ FCS). ICI182780 was introduced $2 \mathrm{~h}$ before $17 \beta$ estradiol and was then present throughout the 24-hour incubation. Values are means \pm SEM of 4-9 observations in each group. ${ }^{* *} \mathrm{p}<0.01 ;{ }^{* * *} \mathrm{p}<0.001$ compared to controls. ${ }^{+++} \mathrm{p}<0.001$ compared to treatment with $3 \mu \mathrm{M}$ E2 alone.

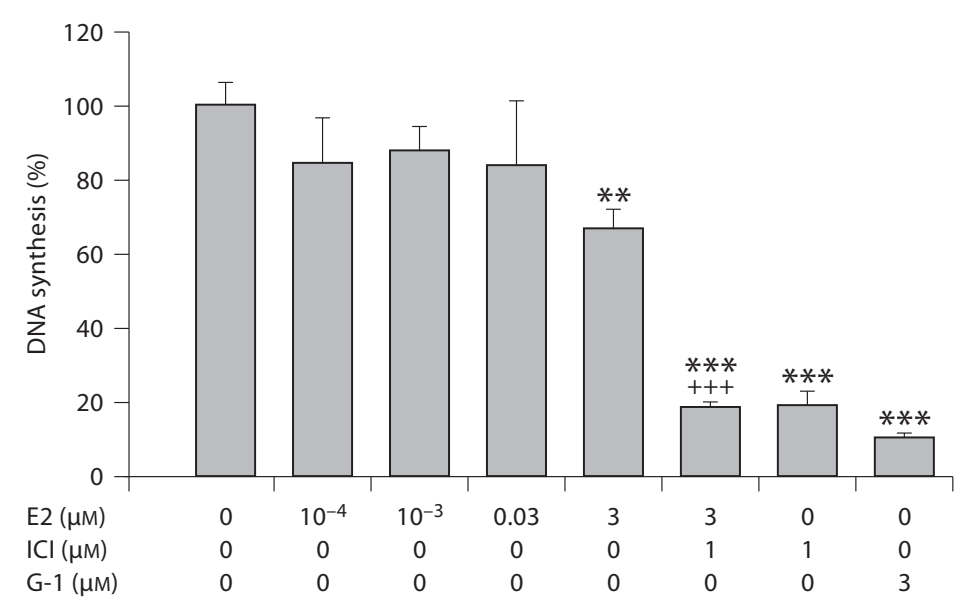

J Vasc Res 2011;48:327-335 

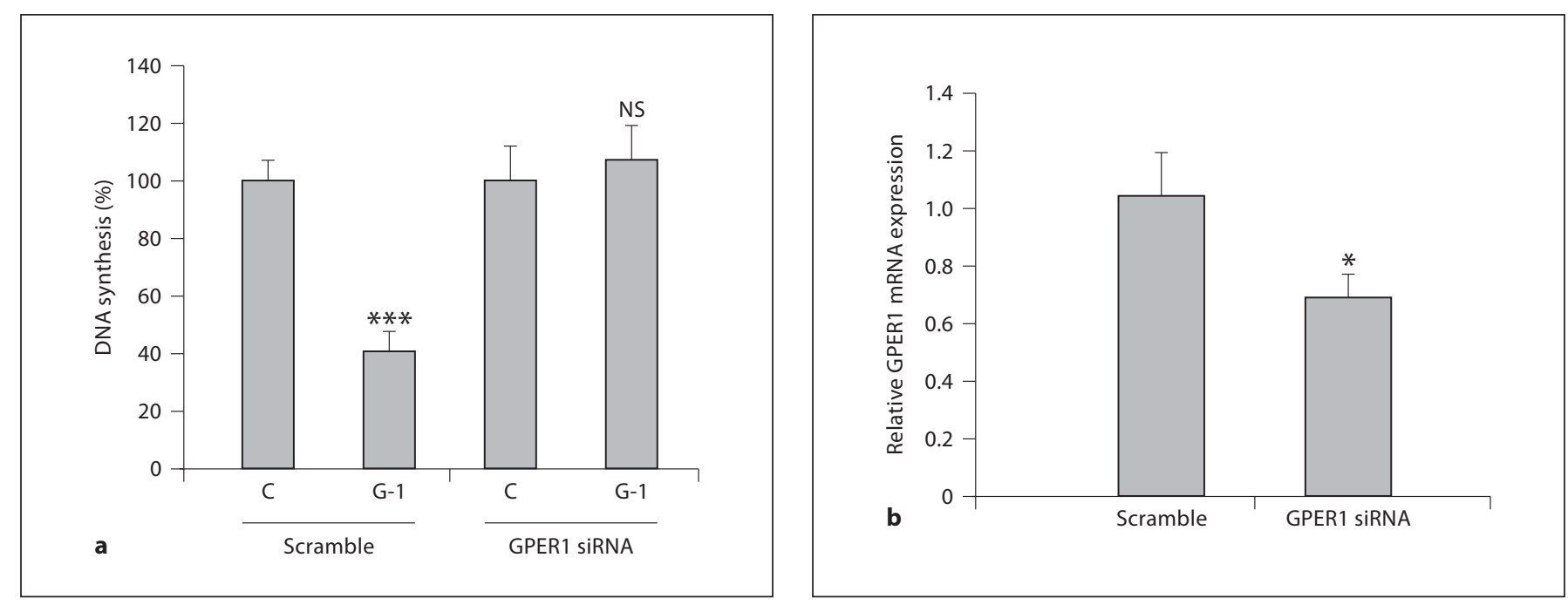

Fig. 5. a GPER1 siRNA abolishes G-1-induced attenuation of DNA synthesis in bEnd.3 cells. The cells were stimulated with G-1 (3 $\mu \mathrm{M})$ for $24 \mathrm{~h}$ under growth-stimulated conditions (5\% stripped FCS). b Downregulation of GPER1 mRNA level by siRNA was confirmed by quantitative real-time PCR. Values are means \pm SEM of $5-6$ observations in each group. ${ }^{*} \mathrm{p}<0.05 ;{ }^{* * *} \mathrm{p}<0.001$. NS $=$ Not significant.

Fig. 6. Treatment with $3 \mu \mathrm{M} \mathrm{G}-1$ for $24 \mathrm{~h}$ reduces DNA synthesis by about $80 \%$ in both bEnd. 3 and HUVEC endothelial cells and by $50 \%$ in HMEC-1 endothelial cells. G-1 ( $3 \mu \mathrm{M})$ has no effect in COS-7 cells. The cells were treated with G-1 under nonstimulated ( $0 \%$ FCS) basal conditions. Values are means \pm SEM of 3-9 observations in each group. ${ }^{*} \mathrm{p}<0.05 ;{ }^{* *} \mathrm{p}<0.01$; *** $\mathrm{p}<0.001$. NS $=$ Not significant.

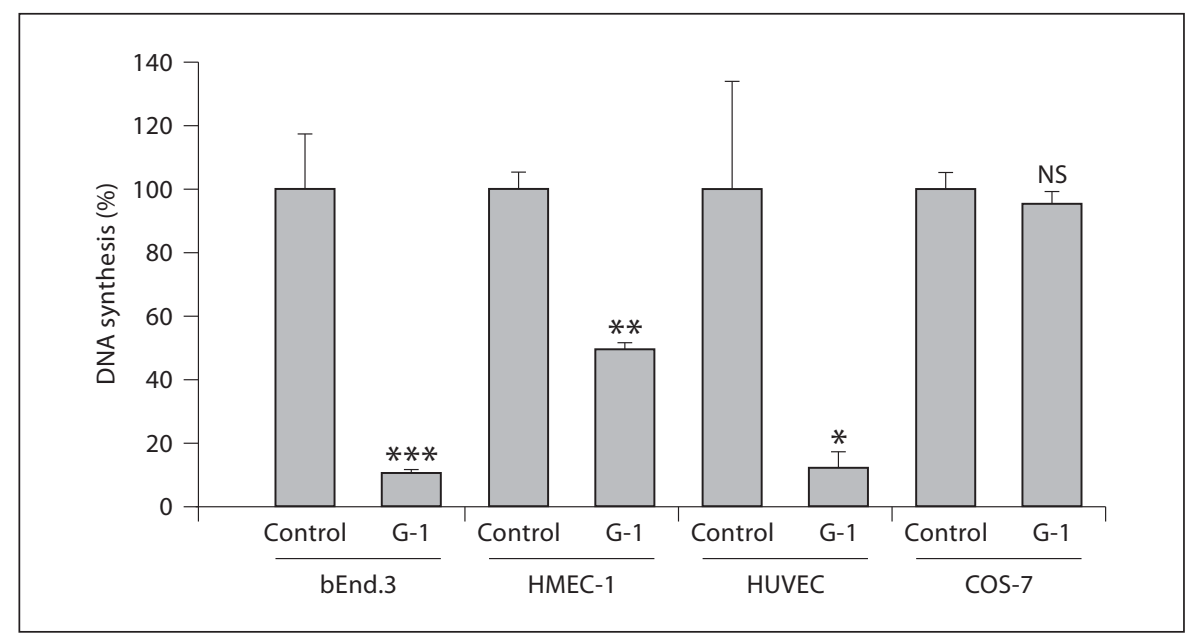

ity (data not shown). Treatment with G-1 ( $3 \mu \mathrm{M})$ for $24 \mathrm{~h}$ under the same culture conditions as used for measuring cell number (see above) accumulated cells in S and G2 phases of the cell cycle (fig. 7b), suggesting that G-1 prevents the endothelial cells from entering the $M$ phase.

\section{Effects of ERK/MAP Kinase Inhibitor PD98059}

on G-1-Induced Inhibition of DNA Synthesis in

bEnd.3 Cells

The ERK/MAP kinase inhibitor PD98059 was included $2 \mathrm{~h}$ before $\mathrm{G}-1$ and then present throughout the 24 - hour incubation ( $0 \%$ FCS) with G-1. As seen in figure 8, combined treatment with PD98059 (1 $\mu \mathrm{M})$ and G-1 $(3 \mu \mathrm{M})$ reduced DNA synthesis similar to G-1 alone, suggesting that G-1-induced reduction of DNA synthesis does not involve attenuation of ERK/MAP kinase activity. PD98059 at $1 \mu \mathrm{M}$ had no effect on DNA synthesis by itself (fig. 8). PD98059 is known to block ERK/MAP kinase activity already at $1 \mu \mathrm{M}$ with an $\mathrm{IC}_{50}$ value of $2 \mu \mathrm{M}$ [30]. Incubation with higher concentrations (10 and 50 $\mu \mathrm{M})$ of PD98059 without G-1 reduced DNA synthesis in a concentration-dependent manner (fig. 8). 

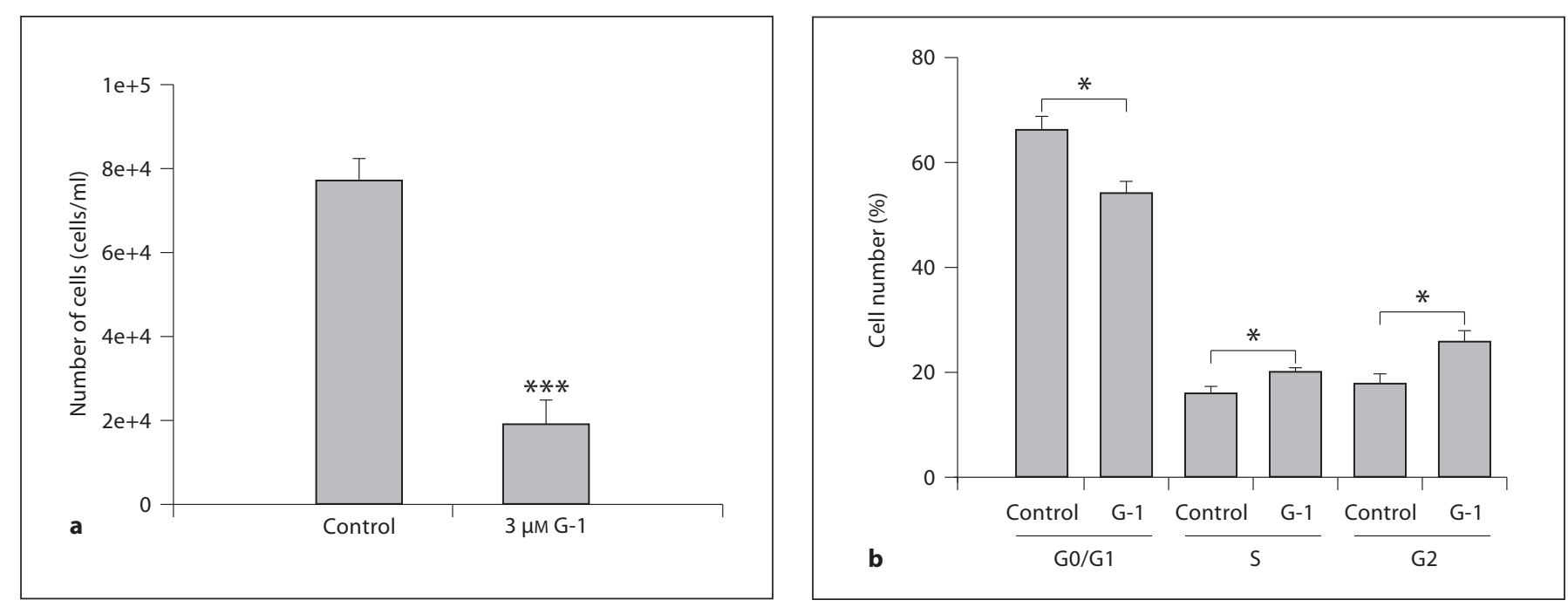

Fig. 7. a Treatment with $3 \mu \mathrm{M}$ G-1 for 5 days in the presence of $5 \%$ stripped FCS reduces bEnd. 3 cell number by about $75 \%$. b Stimulation with G-1 (3 $\mu \mathrm{M})$ for $24 \mathrm{~h}$ in the presence of 5\% stripped FCS accumulates cells in the $\mathrm{S}$ and $\mathrm{G} 2$ phases of the cell cycle. DNA was stained with propidium iodide and distribution of cells in G0/G1, S and G2 phases computed based on DNA histograms and presented as percentage. Values are means \pm SEM of $4-6$ observations in each group. ${ }^{*} \mathrm{p}<0.05 ;{ }^{* * *} \mathrm{p}<0.001$.

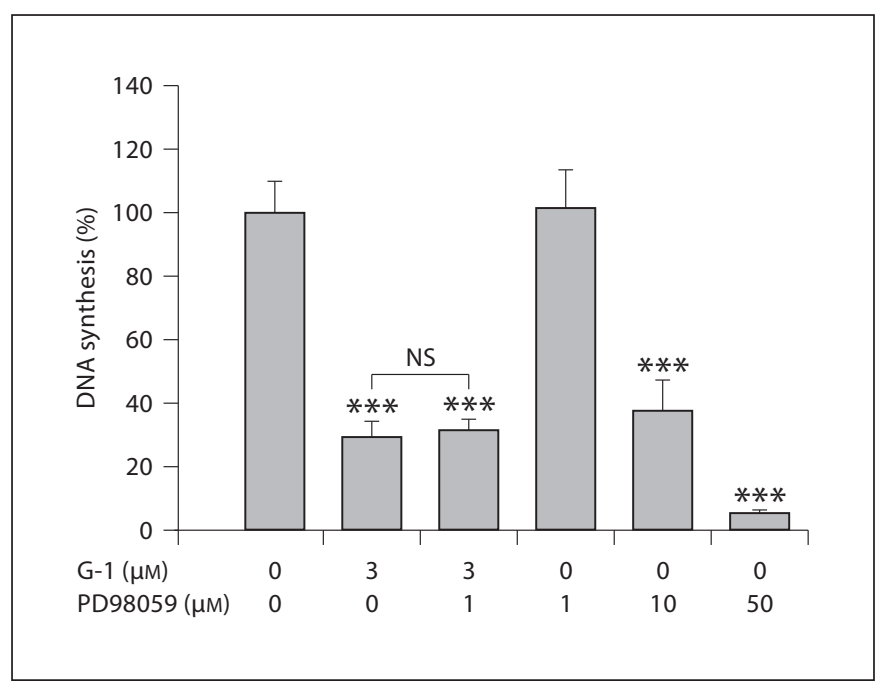

Fig. 8. The ERK/MAP kinase inhibitor PD98059 (1 $\mu \mathrm{M})$ has no effect on G-1-induced ( $3 \mu \mathrm{M})$ inhibition of DNA synthesis in bEnd. 3 cells. PD98059 was introduced 2 h before G-1 and was then present throughout the 24 -hour incubation ( $0 \%$ FCS). Values are means \pm SEM of 3-18 observations in each group. ${ }^{* *} \mathrm{p}<$ 0.001 compared to controls. NS $=$ Not significant.

\section{Discussion}

Here we show that the GPER1 agonist G-1, in the micromolar concentration range, reduces endothelial cell proliferation by inhibiting DNA synthesis and accumulating cells in the $S$ and $G 2$ phases of the cell cycle. G-1induced cell cycle arrest in S and G2 suggests that G-1 prevents the endothelial cells from entering the $M$ phase. Haas et al. [21] reported recently that G-1 at $1 \mu \mathrm{M}$ reduces vascular smooth muscle cell proliferation and proposed that G-1 might be used to attenuate unwanted vascular smooth muscle cell proliferation observed in atherosclerosis. Taken together, these findings suggest that G-1 reduces both endothelial cell and vascular smooth muscle cell proliferation. Unwanted endothelial cell proliferation occurs, for example, in angiogenesis in tumor growth, and G-1 may be used to prevent/reduce this unwanted formation of new blood vessels. Treatment with G-1 has been reported to reduce urothelial cell proliferation as well [28], but in this study growth inhibition by G-1 was observed at a lower concentration (0.01-0.1 $\mu \mathrm{M})$, suggesting that urothelial cells are more sensitive to G-1 than endothelial and vascular smooth muscle cells. The difference in G-1 sensitivity of vascular and urothelial cells suggests that G-1 inhibits proliferation through different mechanisms depending on the cell type. 
In the present study we show that G-1 reduces mouse brain microvascular bEnd. 3 endothelial cell proliferation by inhibition of DNA synthesis and by causing cell cycle arrest in S and G2. G-1-induced attenuation of DNA synthesis was also observed in the widely used and wellcharacterized human dermal microvascular endothelial cell line HMEC-1 $[29,31-33]$ and in HUVEC, showing that G-1-induced reduction of DNA synthesis may be general to endothelial cells independent of origin. The bEnd.3 endothelial cell line is a well-established and widely used endothelial cell line [34, 35]. Furthermore, the bEnd. 3 cells are representative for native endothelial cells as they possess endothelial cell morphology and express the endothelial cell marker protein eNOS [36, 37]. In the present study we show that bEnd. 3 cells express $\mathrm{ER} \alpha, \mathrm{ER} \beta$ and GPER1, confirming their expression patterns observed in endothelial cells in vivo $[11,18]$. The bEnd. 3 cells thus express several endothelial cell markers, suggesting that the G-1-induced antiproliferative mechanism of action that we observe in bEnd. 3 cells is representative of native endothelial cells in vivo.

G-1 has been shown to reduce blood pressure both in normotensive Sprague-Dawley rats and in ovariectomized hypertensive MREN2.LEWIS rats [21, 38]. This agent relaxes rat mesenteric arteries precontracted with either UTP or angiotensin II, human internal mammary arteries precontracted with prostaglandin $\mathrm{F}_{2} \alpha$ and mouse carotid arteries precontracted with prostaglandin $\mathrm{F}_{2} \alpha$, suggesting that the G-1-induced reduction of blood pressure is achieved by reducing vascular resistance $[21,38]$. Acetylcholine-induced vascular relaxation was not affected by G-1, suggesting that G-1 does not act via stimulation of eNOS activity and increased NO production [38]. Relaxation of isolated vascular preparations is observed in response to 1-3 $\mu \mathrm{M} \mathrm{G}-1$, which is in the same concentration range as that reducing proliferation of endothelial and vascular muscle smooth cells. Thus, the GPER1 agonist G-1 affects, in micromolar concentrations, vascular function by reducing vascular resistance but also by attenuation of endothelial and vascular smooth muscle cell proliferation.

The reduction in DNA synthesis by G-1 was unaffected by the ERK/MAP kinase inhibitor PD98059, suggesting that G-1 reduces endothelial cell DNA synthesis via another mechanism than by reducing ERK/MAP kinase activity. We used a concentration of PD98059 known to reduce ERK/MAP kinase activity [30] without having any effects on endothelial cell proliferation, suggesting that G-1 acts via another pathway than ERK/MAP kinase, but still we cannot completely rule out the possibil- ity that G-1, at least in part, acts via ERK/MAP kinase inhibition. The bEnd. 3 endothelial cells express a strong mRNA band for GPER1, suggesting that the antiproliferative effect of G-1 is mediated via GPER1. It is very well documented that COS-7 cells express no GPER 1 or only weakly express this receptor $[27,28]$. Here we show that G-1 reduces DNA synthesis by about $80 \%$ in GPER1-positive bEnd. 3 cells, while it has no effect in COS-7 cells only weakly expressing GPER1 mRNA, suggesting that G-1-induced endothelial cell antiproliferation is mediated by GPER1. The low GPER1 expression level in COS-7 cells is probably not sufficient to evoke antiproliferation upon stimulation by G-1. Another support for the involvement of GPER1 is that the ER antagonist ICI182780, reported to act as a GPER1 agonist [22, 39], reduces endothelial cell DNA synthesis with similar potency as G-1. GPER1 siRNA abolished the G-1-induced attenuation of DNA synthesis, providing direct evidence for the involvement of GPER1. Taken together, these data show that G-1-induced endothelial cell antiproliferation is mediated by the GPER1.

\section{Acknowledgements}

This study was supported by grants from the Swedish Research Council, the Swedish Dental Society, the Crafoord Foundation, the Greta and Johan Kocks Foundation, the European Foundation for the Study of Diabetes/Servier and the Vascular Wall Programme at Lund University. We thank Joanna Daszkiewicz-Nilsson and Ina Nordström for excellent technical assistance.

References $\quad 1$ Mendelsohn ME, Karas RH: The protective effects of estrogen on the cardiovascular system. N Engl J Med 1999;340:1801-1811.

2 Stampfer M, Grodstein F: Cardioprotective effect of hormone replacement therapy is not due to selection bias. BMJ 1994;309:808-809.

- 3 Nathan L, Pervin S, Singh R, Rosenfeld M, Chaudhuri G: Estradiol inhibits leukocyte adhesion and transendothelial migration in rabbits in vivo: possible mechanisms for gender differences in atherosclerosis. Circ Res 1999;85:377-385.

$\checkmark 4$ Nilsson BO: Modulation of the inflammatory response by estrogens with focus on the endothelium and its interactions with leukocytes. Inflamm Res 2007;56:269-273.

5 Chen Z, Yuhanna IS, Galcheva-Gargova Z, Karas RH, Mendelsohn ME, Shaul PW: Estrogen receptor alpha mediates the nongenomic activation of endothelial nitric oxide synthase by estrogen. J Clin Invest 1999;103: 401-406. 
6 Pare G, Krust A, Karas RH, Dupont S, Aronovitz M, Chambon P, Mendelsohn ME: Estrogen receptor- $\alpha$ mediates the protective effects of estrogen against vascular injury. Circ Res 2002;90:1087-1092.

$\checkmark 7$ Brouchet L, Krust A, Dupont S, Chambon P, Bayard F, Arnal JF: Estradiol accelerates reendothelialization in mouse carotid artery through estrogen receptor- $\alpha$ but not estrogen receptor- $\beta$. Circulation 2001;103:423428.

$\checkmark 8$ Krasinski K, Spyridopoulos I, Asahara T, van der Zee R, Isner JM, Losordo DW: Estradiol accelerates functional endothelial recovery after arterial injury. Circulation 1997;95: 1768-1772.

>9 Nilsson S, Makela S, Treuter E, Tujague M, Thomsen J, Andersson G, Enmark E, Pettersson K, Warner M, Gustafsson JA: Mechanisms of estrogen action. Physiol Rev 2001; 81:1535-1565.

-10 Lindner V, Kim SK, Karas RH, Kuiper GG, Gustafsson JA, Mendelsohn ME: Increased expression of estrogen receptor- $\beta$ mRNA in male blood vessels after vascular injury. Circ Res 1998;83:224-229.

-11 Andersson C, Lydrup ML, Ferno M, Idvall I, Gustafsson JA, Nilsson BO: Immunocytochemical demonstration of oestrogen receptor $\beta$ in blood vessels of the female rat. J Endocrinol 2001;169:241-247.

$\checkmark 12$ Vegeto E, Belcredito S, Etteri S, Ghisletti S, Brusadelli A, Meda C, Krust A, Dupont S, Ciana P, Chambon P, Maggi A: Estrogen receptor $\alpha$ mediates the brain anti-inflammatory activity of estradiol. Proc Natl Acad Sci USA 2003;100:9614-9619.

-13 Li L, Haynes MP, Bender JR: Plasma membrane localization and function of the estrogen receptor $\alpha$ variant (ER46) in human endothelial cells. Proc Natl Acad Sci USA 2003; 100:4807-4812.

-14 Figtree GA, McDonald D, Watkins H, Channon KM: Truncated estrogen receptor alpha 46-kDa isoform in human endothelial cells: relationship to acute activation of nitric oxide synthase. Circulation 2003;107:120-126.

15 Thomas P, Pang Y, Filardo EJ, Dong J: Identity of an estrogen membrane receptor coupled to a $G$ protein in human breast cancer cells. Endocrinology 2005;146:624-632.

- 16 Revankar CM, Cimino DF, Sklar LA, Arterburn JB, Prossnitz ER: A transmembrane intracellular estrogen receptor mediates rapid cell signaling. Science 2005;307:16251630.

-17 Filardo EJ, Quinn JA, Bland KI, Frackelton AR Jr: Estrogen-induced activation of Erk-1 and Erk-2 requires the $G$ protein-coupled receptor homolog, GPR30, and occurs via trans-activation of the epidermal growth factor receptor through release of HB-EGF. Mol Endocrinol 2000;14:1649-1660.
18 Isensee J, Meoli L, Zazzu V, Nabzdyk C, Witt H, Soewarto D, Effertz K, Fuchs H, GailusDurner V, Busch D, Adler T, de Angelis MH, Irgang $\mathrm{M}$, Otto $\mathrm{C}$, Noppinger PR: Expression pattern of Gpr30 in LacZ reporter mice. Endocrinology 2009;150:1722-1730.

19 Mårtensson UE, Salehi SA, Windahl S, Gomez MF, Sward K, Daszkiewicz-Nilsson J, Wendt A, Andersson N, Hellstrand P, Grande PO, Owman C, Rosen CJ, Adamo ML, Lundquist I, Rorsman P, Nilsson BO, Ohlsson C, Olde B, Leeb-Lundberg LM: Deletion of the $G$ protein-coupled receptor 30 impairs glucose tolerance, reduces bone growth, increases blood pressure, and eliminates estradiol-stimulated insulin release in female mice. Endocrinology 2009;150:687698.

20 Olde B, Leeb-Lundberg LM: GPR30/GPER1: searching for a role in estrogen physiology. Trends Endocrinol Metab 2009;20:409-416.

21 Haas E, Bhattacharya I, Brailoiu E, Damjanovic M, Brailoiu GC, Gao X, MuellerGuerre L, Marjon NA, Gut A, Minotti R, Meyer MR, Amann K, Ammann E, PerezDominguez A, Genoni M, Clegg DJ, Dun NJ, Resta TC, Prossnitz ER, Barton M: Regulatory role of $\mathrm{G}$ protein-coupled estrogen receptor for vascular function and obesity. Circ Res 2009;104:288-291.

22 Bologa CG, Revankar CM, Young SM, Edwards BS, Arterburn JB, Kiselyov AS, Parker MA, Tkachenko SE, Savchuck NP, Sklar LA, Oprea TI, Prossnitz ER: Virtual and biomolecular screening converge on a selective agonist for GPR30. Nat Chem Biol 2006;2:207212.

23 Pfaffl MW: A new mathematical model for relative quantification in real-time RT-PCR. Nucleic Acids Res 2001;29:e:45.

24 Lowry OH, Rosebrough NJ, Farr AL, Randall RJ: Protein measurement with the Folin phenol reagent. J Biol Chem 1951;193:265275.

25 Odenlund M, Holmqvist B, Baldetorp B, Hellstrand P, Nilsson BO: Polyamine synthesis inhibition induces $S$ phase cell cycle arrest in vascular smooth muscle cells. Amino Acids 2009;36:273-282.

26 Blasko E, Haskell CA, Leung S, Gualtieri G, Halks-Miller M, Mahmoudi M, Dennis MK, Prossnitz ER, Karpus WJ, Horuk R: Beneficial role of the GPR30 agonist G-1 in an animal model of multiple sclerosis. J Neuroimmunol 2009;214:67-77.

27 Ylikomi T, Vienonen A, Ahola T: G proteincoupled receptor 30 down-regulates cofactor expression and interferes with the transcriptional activity of glucocorticoid. Eur J Biochem 2004;271:4159-4168.
28 Teng J, Wang ZY, Prossnitz ER, Bjorling DE: The G protein-coupled receptor GPR30 inhibits human urothelial cell proliferation. Endocrinology 2008;149:4024-4034.

29 Ades EW, Candal FJ, Swerlick RA, George VG, Summers S, Bosse DC, Lawley TJ: HMEC-1: establishment of an immortalized human microvascular endothelial cell line. J Invest Dermatol 1992;99:683-690.

30 Alessi DR, Cuenda A, Cohen P, Dudley DT, Saltiel AR: PD098059 is a specific inhibitor of mitogen-activated protein kinase kinase in vitro and in vivo. J Biol Chem 1995;270: 27489-27494.

31 Vassale C, Domenici C, Lubrano V, L'Abbate A: Interaction between nitric oxide and cyclooxygenase pathway in endothelial cells. J Vasc Res 2003;40:491-499.

32 Selemidis S, Dusting GJ, Peshavariya H, Kemp-Harper BK, Drummond GR: Nitric oxide suppresses NADPH oxidase-dependent superoxide production by S-nitrosylation in human endothelial cells. Cardiovasc Res 2007;75:349-358.

-33 Guo YL, Bai R, Chen CX, Liu DQ, Liu Y, Zhang CY, Zen K: Role of junctional adhesion molecule-like protein in mediating monocyte transendothelial migration. Arterioscler Thromb Vasc Biol 2009;29:75-83.

34 Omidi Y, Campbell L, Barar J, Connell D, Akhtar S, Gumbleton M: Evaluation of the immortalised mouse brain capillary endothelial cell line, b.End3, as an in vitro bloodbrain barrier model for drug uptake transport studies. Brain Res 2003;990:95-112.

>35 Brown RC, Morris AP, O’Neil RG: Tight junction protein expression and barrier properties of immortalized mouse brain microvessel endothelial cells. Brain Res 2007; 1130:17-30.

36 Bevers, LM, Braam B, Post JA, van Zonneveld AJ, Rabelink TJ, Koomans HA, Verhaar MC, Joles JA: Tetrahydrobiopterin, but not L-arginine, decreases NO synthase uncoupling in cells expressing high levels of endothelial NO synthase. Hypertension 2006;47:87-94.

37 Odenlund M, Ekblad E, Nilsson BO: Stimulation of oestrogen receptor-expressing endothelial cells with oestrogen reduces proliferation of cocultured vascular smooth muscle cells. Clin Exp Pharmacol Physiol 2008; 35:245-248.

38 Lindsey SH, Cohen JA, Brosnihan KB, Gallagher PE, Chappell MC: Chronic Treatment with the Gpr30 agonist G-1 decreases blood pressure in ovariectomized Mren2.Lewis rats. Endocrinology 2009;150:3753-3758.

>39 Kuhn J, Dina OA, Goswami C, Suckow V, Levine JD, Hucho T: GPR30 estrogen receptor agonists induce mechanical hyperalgesia in the rat. Eur J Neurosci 2008;27:1700-1709. 